\begin{tabular}{|c|c|c|}
\hline $\begin{array}{c}\text { RESEARCH } \\
\text { ARTICLE }\end{array}$ & $\begin{array}{r}\text { ADVANCE RESEARCH JOURNAL O } \\
\text { volume } 6 \mid \text { Issue } 2 \mid \text { December, } 2015 \mid 191-197\end{array}$ & $\begin{array}{l}\text { F SOCIAL SCIENCE } \\
\text { e ISSN-2231-6418 }\end{array}$ \\
\hline $0=$ & DOI: 10.15740/HAS/ARJSS/6.2/191-197 & Visit us : www.researchjournal.co.in \\
\hline
\end{tabular}

\title{
Leisure time activities: A boost for elderly health
}

S. Badami* and G.V. Yenagi ${ }^{1}$

Department of Human Development and Family Studies, College of Rural Home Science, University of Agricultural Sciences, DHARWAD (KARNATAKA) INDIA

(Email : badami.sumangala8@gmail.com)

${ }^{1}$ Department of Psychology, College of Agriculture, University of Agricultural Sciences, DHARWAD (KARNATAKA) INDIA

\section{ARTICLE INFO :}

$\begin{array}{lll}\text { Received } & : & 11.08 .2015 \\ \text { Revised } & : & 28.10 .2015 \\ \text { Accepted } & : & 09.11 .2015\end{array}$

KEY WORDS :

Ageing, Elderly, Health status, Leisure time activities, Gender and health, Health and leisure activity

\section{HOW TO CITE THIS ARTICLE :}

Badami, S. and Yenagi, G.V. (2015). Leisure time activities: A boost for elderly health. Adv. Res. J. Soc. Sci., 6 (2) : 191197.
*Author for correspondence

\section{ABSTRACT}

Forty Five rural and urban male and female elderly under the age group of 60-74, 75-84 and 85 and above were randomly selected from Dharwad Taluka. Data was collected through exploratory and personal interview methods. Individually administered questionnaire consisted of personal information schedule to elicit auxiliary information of the subjects regarding demographic variables, Ageing scale was used to assess the health status and leisure time activities of elderly and socio-economic status scale was employed to assess the SES of the family. To find out the association between health status, leisure time activities and independent variables non-parametric test was employed. Correlation research design was employed to test the degree of relationship between health status and leisure time activities of rural and urban elderly. Results showed that 58.50 per cent of rural elderly belonged to lower middle SES and 47.40 per cent of the urban elderly belonged to upper middle SES. With respect to health problems, majority of the elderly had no health problems such as tremors $(83.1 \%)$, asthma (79.4\%), heart problem (79.1\%), constipation (77.7\%), headache (76.3\%), heal pain (74.4\%), skin itching (71.8\%), poor hearing (67.4), reproductive problems $(67.2 \%)$, acidity (64.8\%), nerve problem (64.3\%), uncontrollable bladder (52.4\%), diabetes (46.3\%), back pain (43\%). Significant association was found between health status and gender of the rural elderly. Whereas non-significant association was found between health status and gender of the urban elderly. Majority of the rural and urban elderly under age group of 60-74 years old had good health status. Significant association was found between health status and age of the rural elderly. Whereas, it was no significant in case of urban elderly. Majority of the elderly reported of involving in leisure time activities regularly like Going out for walk (76.7\%), Involving in religious activities (75.2\%), Visiting friends (70.2\%), Sleeping (63.3), watching TV (63\%), Gardening (60.9), Listening to music (57.6), Caring for grand children (40.6), Reading (32.4), Participating in sports/games (20.6), Working part/full time (18.1) and Participating in community organization. health status was positively and significantly correlated with leisure time activities of the elderly $(\mathrm{r}=0.33)$. Indicating higher the engagement in the leisure time activities, better the health status of the elderly. 